\title{
Alcaligenes faecalis associated with Mimosa calodendron rizhosphere assist plant survival in arsenic rich soils
}

\author{
Érica Barbosa Felestrino ${ }^{1}$, Renata de Almeida Barbosa Assis ${ }^{1}$, Camila Gracyelle de \\ Carvalho Lemes $^{1}$, Isabella Ferreira Cordeiro ${ }^{2}$, Natasha Peixoto Fonseca ${ }^{1}$, Morghana Marina \\ Villa $^{3}$, Izadora Tabuso Vieira ${ }^{3}$, Luciana Hiromi Yoshino Kamino ${ }^{4}$, Flávio Fonseca do \\ $\mathrm{Carmo}^{4}$, and Leandro Marcio Moreira ${ }^{1,5^{*}}$
}

${ }^{1}$ Programa de Pós-graduação em Biotecnologia, Núcleo de Pesquisas em Ciências Biológicas (NUPEB), Universidade Federal de Ouro Preto, Ouro Preto, MG, Brasil. ${ }^{2}$ Programa de Pós-graduação em Biomas Tropicais, Universidade Federal de Ouro Preto, Ouro Preto, MG, Brasil. ${ }^{3}$ Laboratório de Bioquímica e Biologia Molecular, Universidade Federal de Ouro Preto, Ouro Preto, MG, Brasil. ${ }^{4}$ Instituto Prístino, Belo Horizonte, MG, Brasil. ' Departamento de Ciências Biológicas (DECBI), Instituto de Ciências Exatas e Biológicas, Universidade Federal de Ouro Preto, Campus Morro do Cruzeiro, Ouro Preto, MG, Brasil. *Corresponding author:lmmorei@iceb.ufop.br

\begin{abstract}
The ferruginous rupestrian grasslands (FRG) in the Iron Quadrangle (IQ) are ecosystems characterized by rocky soils with reduced availability of water and nutrients, but high levels of metals. In order to comprehend the interference of microorganisms on the adaptive process of endemic plant Mimosa calodendrum (Fabaceae), bacteria associated with its roots and rhizosphere were isolated. Fourteen isolates were obtained and subsequently grown in the presence of different concentrations of arsenic (As) species. The isolate Mc250, an Alcaligenes faecalis strain, resisted to $10 \mathrm{mM}$ of As (III) and $800 \mathrm{mM}$ of As (V). In the presence of this strain, atomic spectrometer detected a reduction of $55 \%$ for As (III) and $72 \%$ for As (V) respectively in $10 \mathrm{mM}$ and $500 \mathrm{mM}$ solution. Scanning electron microscopy of this isolate demonstrated morphological modification and EDX spectroscopy revealed the presence of both As species adsorbed on the membrane, justifying the removal observed in the in vitro assays. To validate this potential removal of As in vivo, tomato plants were used as grown model in the presence and absence of A. faecalis in soil previously contaminated with $5 \mathrm{mM}$ of As (III). After 14 days, plants from contaminated soil had their growth improved when compared to untreated control plants. All these results suggest for the first time that plant-associated bacteria from FRG-IQ present potential for soil rhizoremediation and may benefit the adaptive processes of plants in extreme environments including application in recovering degraded areas.
\end{abstract}

Keywords: Arsenic removal, arsenic resistant bacteria, Iron Quadrangle, Mimosa calodendron, plant growthpromoting rhizobacteria, rhizoremediation. 


\section{Introduction}

The Iron Quadrangle (IQ), an area of approximately $7200 \mathrm{~km}^{2}$ located in the south central region of Minas Gerais State, Brazil. That is remarkable for the giant iron and gold ore reserves (Figure 1A).
Therefore, mining activity in this region placed Brazil as the second largest world provider of iron ore. In 2014, around 400 million tons were produced, most of which extracted from IQ, which concentrates almost $80 \%$ of iron mines in activity (Salgado and Carmo, 2015).

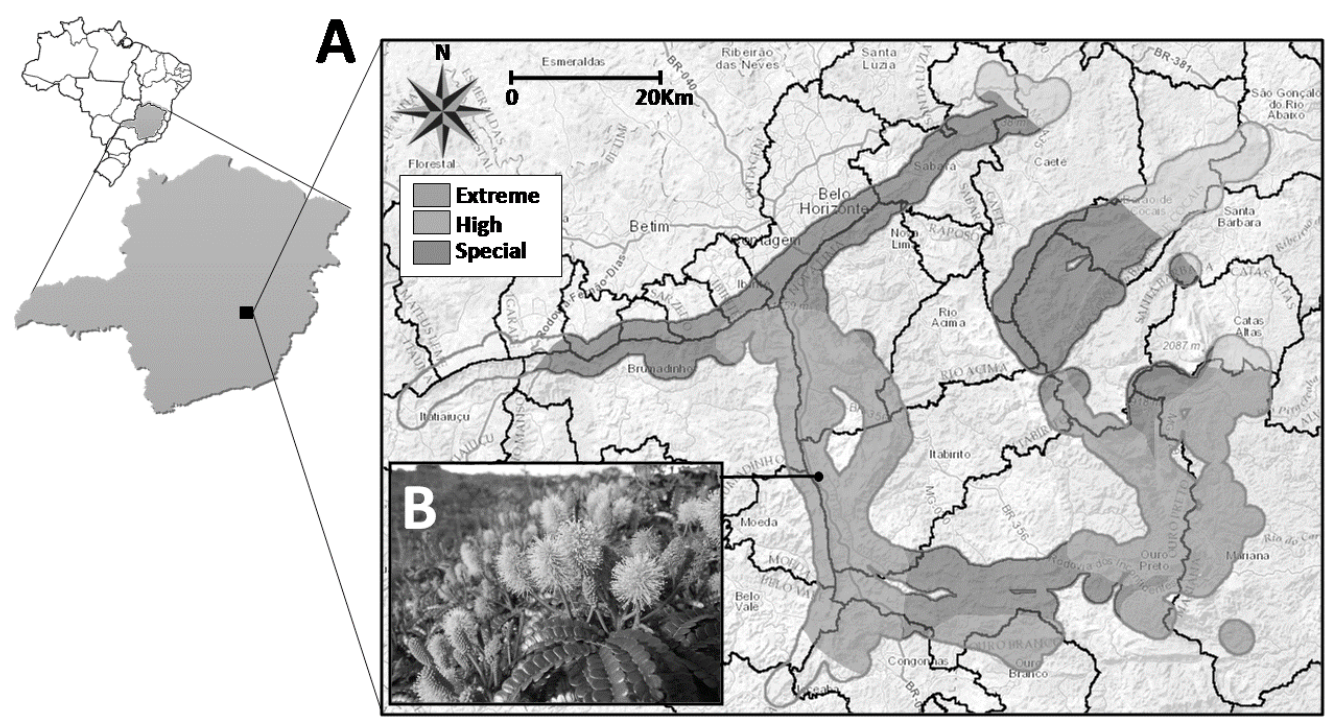

Figure 1. Iron Quadrangle geographical location and area where Mimosa calodendron was sampled. A) IQ location highlighting elevated areas that stand out on their vertices. The colors identify the priority areas for biodiversity conservation of Minas Gerais flora (see legend) obtained from the digital atlas Geoambiental (http://www. institutopristino.org.br/atlas). B) Identification of the area in Moeda Mountain where Mimosa calodendron was sampled.

The high geochemical diversity and intense mining activities resulted in soils and stream sediments with anomalous concentrations of many different trace elements such as $\mathrm{Zn}, \mathrm{Pb}, \mathrm{Ni}, \mathrm{Cr}$, and As. Arsenic is a heavy metal extremely toxic to any organism and its toxicity mechanisms in plants are well established (Seshadri et al., 2015). Average concentrations of arsenic in soils from the IQ regions are around 960 $\mathrm{mg} / \mathrm{kg}$, though in some situations it might reach up to 13400 mg/kg. These higher As-concentrations gen- erally occur associated with magmatic sulfides and iron ores (Vicq et al., 2015).

The iron geosystem of IQ consists of Cretaceous limonite cemented iron-caps, named cangas, and other lithotypes composed by high concentrations of metallic minerals especially iron and manganese. The extreme environmental conditions of cangas such as surface temperatures up to nearly $70^{\circ} \mathrm{C}$, acids and impoverished soils, and substrates with high concentrations of metallic minerals, maintain plant 
communities characterized by a rarity and high degree of endemism (Carmo and Jacobi, 2016). The plant endemism in this region is directly related to their morphophysiological adaptations associated with production of osmolytes, alteration in water transport, and detoxification of reactive oxygen species (Vincent and Meguro, 2008). Due to the presence of such adaptive traits, these plants are characterized as metalliferous, which can be grouped as hyperaccumulators, metallophytes (with endemic taxa from metal-bearing areas), and pseudometallophytes.

In southeastern of Brazil these peculiar vegetation is classified as Ferruginous Rupestrian Grasslands (FRG) (Silveira et al., 2016). Metallophytes communities of plants from FRG represent one of the most relevant for conservation purposes since they can provide ecological services such as phytoextraction, phytostabilization, and phytoprospection (Ginocchio and Baker, 2004), being for some authors considered a diversity hotspot region (Silveira et al., 2016). In FRG, sixty canga endemic plants were catalogued (Carmo and Jacobi, 2012); however, a few have been better characterized in an ecological context, as is the case of the leguminous Mimosa calondendron Mart. ex Benth (Fabaceae).

This nodulating shrubby leguminous species may be an important N2 fixer, and even act as a "nurse plant" promoting, for example, shadowing, which in turn would favor the recruitment and establishment of seedlings. Nevertheless, there are no studies connecting Mimosa calodendron or any other endemic species from this region with the soil microbiota, except a few works demonstrating the relationship of some of these plants to phosphate metabolism (Matias et al., 2009). In contrast, it is known for other models the importance of Plant Growth-Promoting Rhizobacteria (PGPR) in the maintenance and growth of plant species that can act in bioremediation, biocontrol, and biofertilization (Jimtha et al, 2016; Banerjee et al,
2017). In this context, they seem to be fundamental to survival, maintenance and adaptation of plants to FRG.

Based on this geochemical and environmental perspective, the main purpose of this study was to investigate, although in a preliminary and focused manner, the importance of bacteria associated with the roots and rhizosphere of Mimosa calondendron, as bioremediator of soils contaminated with high As concentrations.

\section{Materials and Methods}

\subsection{Plant sample collection}

Three Mimosa calodendron roots and rizhosphere samples were collected from the Moeda Mountains (latitude $20^{\circ} 15^{\prime} 83^{\prime} \mathrm{S}$, longitude $43^{\circ} 97^{\prime} 41^{\prime \prime} \mathrm{W}$ ), Minas Gerais State, Brazil (Figure 1B). The samples were transferred to laboratory 4 hours after collected.

\subsection{Bacterial isolation}

The samples were serially diluted (up to $10^{-6}$ ) and inoculated in Petri dishes $(60 \times 15 \mathrm{~mm})$ containing Luria-Bertani (LB) agar medium (tryptone 10 $\mathrm{g} / \mathrm{L}$, yeast extract $5 \mathrm{~g} / \mathrm{L}$, sodium chloride $10 \mathrm{~g} / \mathrm{L}$, agar $15 \mathrm{~g} / \mathrm{L}$, adjusted to $\mathrm{pH} 7.0$ ). The root samples were washed to external disinfection following the steps: $9 \mathrm{~g} / \mathrm{L} \mathrm{NaCl}$ solution for $2 \mathrm{~min}, 70 \%$ alcohol for $2 \mathrm{~min}, 2 \%$ sodium hypochlorite solution for 2 min, and $9 \mathrm{~g} / \mathrm{L} \mathrm{NaCl}$ solution for $2 \mathrm{~min}$. Slices of roots pre-disinfected were inoculated on LB agar medium surface. In both cases, the plates were incubated at $28{ }^{\circ} \mathrm{C}$ for up to seven days. To isolate bacterial strains, the colonies were individually streaked in another Petri dish containing LB agar medium. Fourteen isolates were originally 
obtained and kept in LB medium slants in $15 \%$ glycerol at $-80{ }^{\circ} \mathrm{C}$.

\subsection{BOX-PCR-based identification of bacterial species}

BOX-PCR analysis was used to verify molecular characterization of bacterial isolates (Versalovic et al., 1991). The PCR reaction was prepared to a final volume of $25 \mu 1$ containing: $2 \mu 1$ of DNA, 4 $\mu 1$ primer BOX (BOX 1AR) 50 pmol, $4 \mu \mathrm{l}$ of PCR buffer $5 \mathrm{X}$ (Fermentas), $1 \mu \mathrm{l} 25 \mathrm{mM} \mathrm{MgCl}, 3 \mu \mathrm{l}$ dNTP $10 \mathrm{mM}, 0.3 \mu \mathrm{l}$ of $5 \mathrm{U}$ TaqDNA polymerase (Fermentas), and the final volume filled with sterile distilled water. The PCR thermocycler (Biosystems) was used under the following conditions: initial denaturation at $95^{\circ} \mathrm{C}$ for 5 minutes followed by 35 cycles of 1 minute denaturation at $95{ }^{\circ} \mathrm{C}, 1$ minute annealing at $53{ }^{\circ} \mathrm{C}$, and 2 minute extension at $72{ }^{\circ} \mathrm{C}$. A final extension was incorporated for 10 minutes at $72{ }^{\circ} \mathrm{C}$. PCR products were analyzed by $0.8 \%$ agarose gel electrophoresis in $1 \mathrm{x}$ TBE buffer, eluted in $6 \mathrm{X}$ run buffer stained with ethidium bromide for approximately $30 \mathrm{~min}$ at $120 \mathrm{~V}$.

\subsection{Arsenic resistance assays}

All isolated bacterial strains were screened for arsenic resistance assay. These strains were grown on LB plates containing different concentration of As (V) $\left(\mathrm{Na}_{2} \mathrm{HAsO}_{4}\right)$ ranging from 0.5 to $500 \mathrm{mM}$ $\left(\sim 150\right.$ to $\left.250.000 \mathrm{mg} \mathrm{kg}^{-1}\right)$ and As (III) $\left(\mathrm{NaAsO}_{2}\right)$ ranging from 0.1 to $10 \mathrm{mM}\left(\sim 13\right.$ to $1.300 \mathrm{mg} \mathrm{kg}^{-}$ $\left.{ }^{1}\right)$. All plates were incubated at $28{ }^{\circ} \mathrm{C}$ for up to 3 days. Mimosa calodendron isolate 250 (Mc250) was found to be resistant to $800 \mathrm{mM} \mathrm{As} \mathrm{(V)} \mathrm{and} 10$
mM As (III). This bacterial strain has been selected for further analysis.

\subsection{Identification of Mc250 strain}

Pure culture of Mc250 strain was grown overnight in LB medium for the isolation of genomic DNA using QIAmp ${ }^{\circledR}$ DNA Stool Mini Kit (Qiagen) following the manufacturer's instructions. The identification was carried out through PCR amplification of $16 \mathrm{~S}$ rDNA. The As resistant isolate was named Alcaligenes faecalis strain Mc250 and its sequence data have been deposited in the GenBank (accession number KY271067). Sequence analysis of the isolate was compared with $16 \mathrm{~S}$ rDNA sequences using Blastn search.

\subsection{Growth curve of A. faecalis strain Mc250}

In order to study the effect of metal concentration on bacterial growth, A. faecalis strain Mc250 was inoculated in LB broth with and without $10 \mathrm{mM}$ As (III) and $800 \mathrm{mM} \mathrm{As}(\mathrm{V})$, and incubated at $28^{\circ} \mathrm{C}$ under shaking conditions at $180 \mathrm{rpm}$. Growth was monitored spectrophotometrically at $600 \mathrm{~nm}$ at every three hours until constant readings were observed in control and test samples.

\subsection{In vitro arsenic removal capacity by A. faecalis strain Mc250}

The A. faecalis strain Mc250 was grown at $28^{\circ} \mathrm{C}$ in two Erlenmeyer flasks of $500 \mathrm{~mL}$ containing both $300 \mathrm{~mL}$ nutrient broth and $500 \mathrm{mM}$ As (V) and $10 \mathrm{mM}$ As (III) each one. As-free media was taken as a control. The flasks were placed in an orbital shaker at $150 \mathrm{rpm}$ at $28{ }^{\circ} \mathrm{C}$. Culture broth 
of $10 \mathrm{~mL}$ was collected, centrifuged, and the supernatant analyzed by atomic absorption spectrophotometry. Finally, total arsenic and other heavy metals were determined.

\subsection{Scanning Electron Microscopy and Energy} Dispersive X-ray Spectroscopy (SEM/EDS)

The sixteen-hours grown culture of A. faecalis strain Mc250 was inoculated $(1 \%, \mathrm{v} / \mathrm{v})$ in two LB plates with $500 \mathrm{mM}$ of $\mathrm{As}(\mathrm{V})$ and $10 \mathrm{mM}$ of As (III) respectively, and incubated for $72 \mathrm{~h}$ at $28{ }^{\circ} \mathrm{C}$. Cells were harvested after incubation by centrifugation and washed twice with sodium phosphate buffer ( $\mathrm{pH}$ 7.4). Cells were then fixed with paraformaldehyde solution $(0.5 \%)$ and washed twice with sodium phosphate buffer. Dehydration of cells was carried out in gradient of ethanol, and the fixed cells were sputtered with gold nanostructures (Focardi et al., 2010). The scanning electron microscopy observation and energy dispersive X-ray spectroscopy analyses were performed at NanoLab of Centro Mínero-Metalúrgico da Rede Temática em Engenharia de Materiais (CMM-REDEMAT).

\subsection{Experimental assay using tomato plants}

A greenhouse experiment was conducted to evaluate the effect of bacterial isolates on plant growth and As uptake by tomato Santa Clara 5800 cultivar. It was previously performed a tomato growth curve for different concentrations of As (III) in order to detect which metal concentration affects plant growth. The limiting concentration of $5 \mathrm{mM}$ was established for As (III). The soil sample was contaminated with $5 \mathrm{mM}$ of As (III) and two days later, 20 tomato seeds were planted in the flask and inoculated with bacteria resistant to metal (Mc250).
The culture was previously prepared by growing in liquid LB to reach 1 O.D. and centrifuged for 10 minutes at $5000 \mathrm{rpm}$. The pellet was resuspended in tap water and this solution was inoculated in the contaminated soil. After 14 days of growth, the plants had the stem size, root, and germination rate measured.

\section{Results}

\subsection{Arsenic resistance assay}

A total of 14 isolates were obtained from the collected samples. All of them were tested in different concentrations of arsenite varying from 0.5 to $10 \mathrm{mM}$; and arsenate varying from 1 to $1000 \mathrm{mM}$. Three isolates stood out because they resisted to elevated concentrations of both arsenic species investigated: Mc250 and Mc251 (10 mM As (III) and $800 \mathrm{mM}$ As (V)), and Mc252 (5 mM As (III) and $800 \mathrm{mM}$ As (V)), all associated with Mimosa calodendron rhizosphere. Before the selection of resistant isolates for the further tests, a PCR was performed with BOX primer in order to evaluate the genetic similarity of the isolates through band patterns analyses (Figure 2). As a result, Mc250 and Mc251 isolates had the same band pattern suggesting that they are the same microorganism. Thus, as their resistance capacity was the highest, in-depth studies were carried out with Mc250.

\subsection{Identification of the resistant isolate $M c 250$}

Using 16s rRNA sequencing, the arsenic resistant bacteria Mc250 was identified as belonging to Alcaligenes faecalis strain (GenBank accession number KY271067) with 99\% identity with other bacteria of the same genera and specie. 


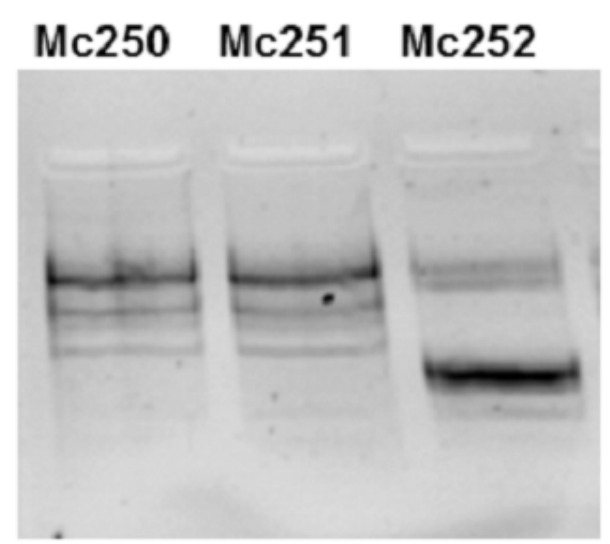

Figure 2. PCR with BOX primer using Mc250, Mc251, and Mc252 isolates. Mc250 and Mc251 isolates showed the same band pattern suggesting they are the same microorganism.

\subsection{Effect of arsenic on growth of $A$. faecalis strain Mc250}

The minimum inhibitory concentration (MIC) for sodium arsenite was $12.5 \mathrm{mM}$ in LB broth, where $99 \%$ of cellular growth inhibition for A. faecalis strain Mc250 was observed (Figure 3A). The isolate growth curve in the presence and absence of As (III) and As (V) is shown in Figure 3B.
A. faecalis strain Mc250 exhibited a stationary phase with 24 hours. Besides different OD values, these strain showed a stationary phase with 54 hours in the presence of both As species. Compared to the control, the strain Mc250 showed a prolonged lag phase in both conditions (presence of both As species). Thus, it is likely that this differential growth rate reflects the protein expression patterns of $A$. faecalis strain Mc250 under stress caused by As.
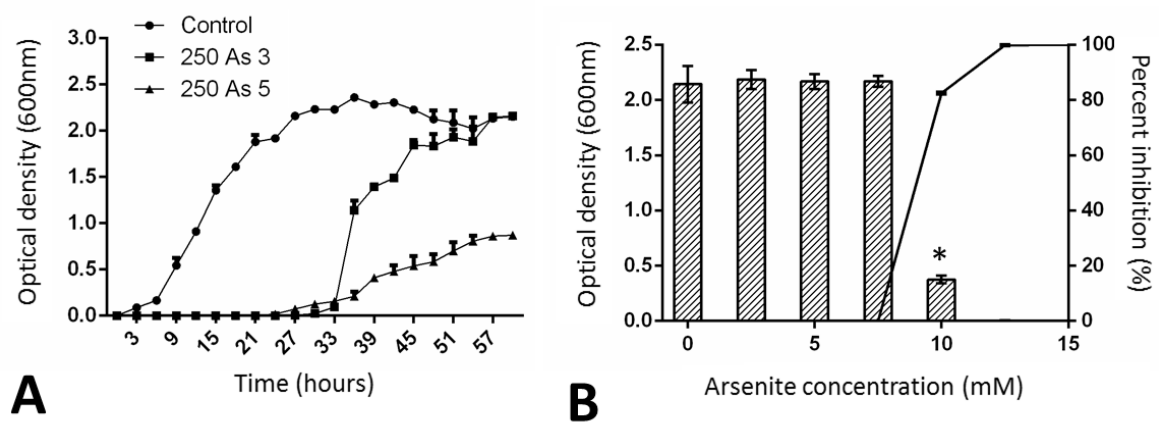

Figure 3 A) Growth curve of $A$. faecalis strain Mc250 in LB broth without As (circle), in LB broth with $10 \mathrm{mM}$ of As (III) (square) and in LB broth with $800 \mathrm{mM}$ of As (V) (triangle). B) Minimum inhibitory concentration (MIC) of As (III) (graph bar) and percentage of inhibition of A. faecalis strain Mc250 cells in different concentrations of As (III) (line graph). The asterisk above bars indicate statistically significant difference among the groups $(p<0.05)$. 


\subsection{As (III) and As (V) removal in culture media}

The atomic spectrometer detected a reduction of approximately $55 \%$ of As (III) in a $10 \mathrm{mM}$ solution, and a removal of approximately $72 \%$ of As (V) in a 500 $\mathrm{mM}$ solution in the presence of the isolate Mc250 (Table 1).

Table 1. Removal values of As (III) and As (V) in the presence of A.faecalis strain Mc250.

\begin{tabular}{lll}
\cline { 2 - 3 } & {$[\mathbf{A s}(\mathbf{I I I})] \mathbf{~ m g} / \mathbf{L}(\mathbf{S D})$} & {$[\mathbf{A s}(\mathbf{V})] \mathbf{~ m g} / \mathbf{L}(\mathbf{S D})$} \\
\hline Initial & 689.2 & $55,100.0$ \\
Final & $380.4( \pm 12.3)$ & $39,500.0( \pm 1,670.0)$ \\
\% removal & $55,2 \%( \pm 1,79)$ & $71,7 \%(2,32)$ \\
\hline
\end{tabular}

SD - Standard deviation

\subsection{Changes in cell morphology}

The scanning electron microscopy (SEM) of A. faecalis strain Mc250 cells without (control) and with exposure to As (III) and As (V) are shown in Figure 4A-C, respectively. SEM analysis of the arsenic treated and untreated cells displayed distinct changes in cell size. The effect of arsenic was visible through increase in cell volume. This remarkable increase in cell volume may be interpreted as a possible strategy of the cell to improve the accumulation of arsenic from the surrounding environment in order to minimize its toxicity. However, in both situations cells were flat and showed intact surfaces. The energy dispersive $\mathrm{X}$-ray spectroscopy (EDS) revealed the presence of As (III) and As (V) adsorbed on the membrane of this isolate.
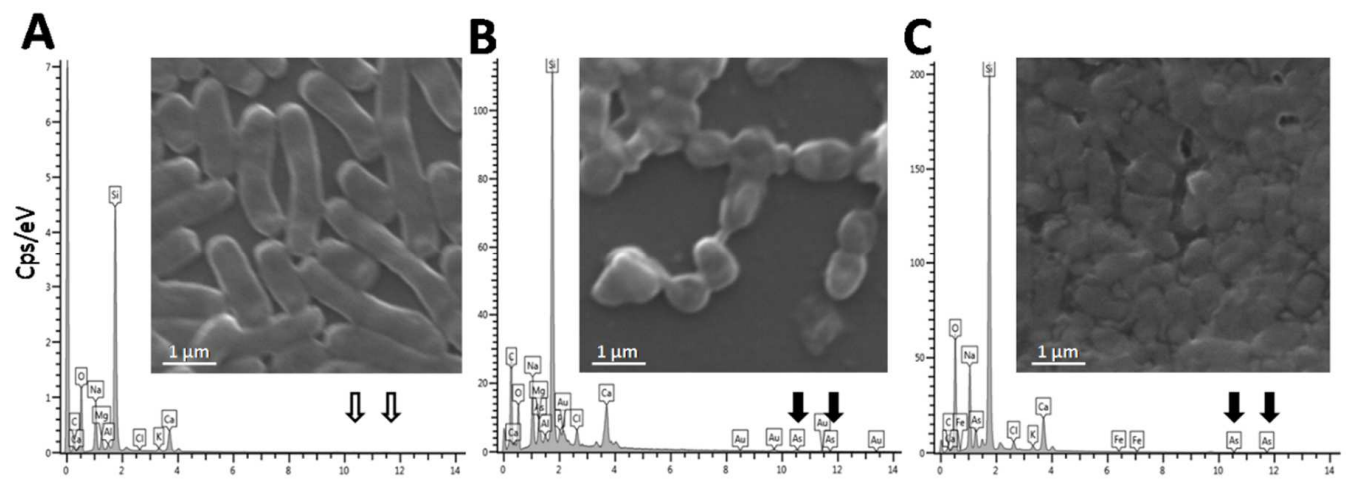

Figure 4. Scanning electron microscopy (SEM) of A. faecalis strain Mc250 cells without As (control) (A) and with exposure to As (III) (B) and As (V) (C) with respective EDS. 
3.6. Effect of A. faecalis strain Mc250 in tomato growth in As-contaminated soil

Tomato growth curve in the presence of As (III) revealed $5 \mathrm{mM}$ as a limit concentration for a satisfactory growth. Although there was no statistical significance through Kruskal-Wallis and Dunn`s test analysis (Figure 5C), a relevant visual growth improvement was detected as shown in Figure $5 \mathrm{AB}$. Moreover, the presence of $A$. faecalis strain Mc250 in soil contaminated with this As (III) concentration demonstrated an improvement in the germination rate $(15 \%)$, and stem size $(10 \%)$. These differences are demonstrated in the graphic and in Figure 5CD with the phenotype reversion.

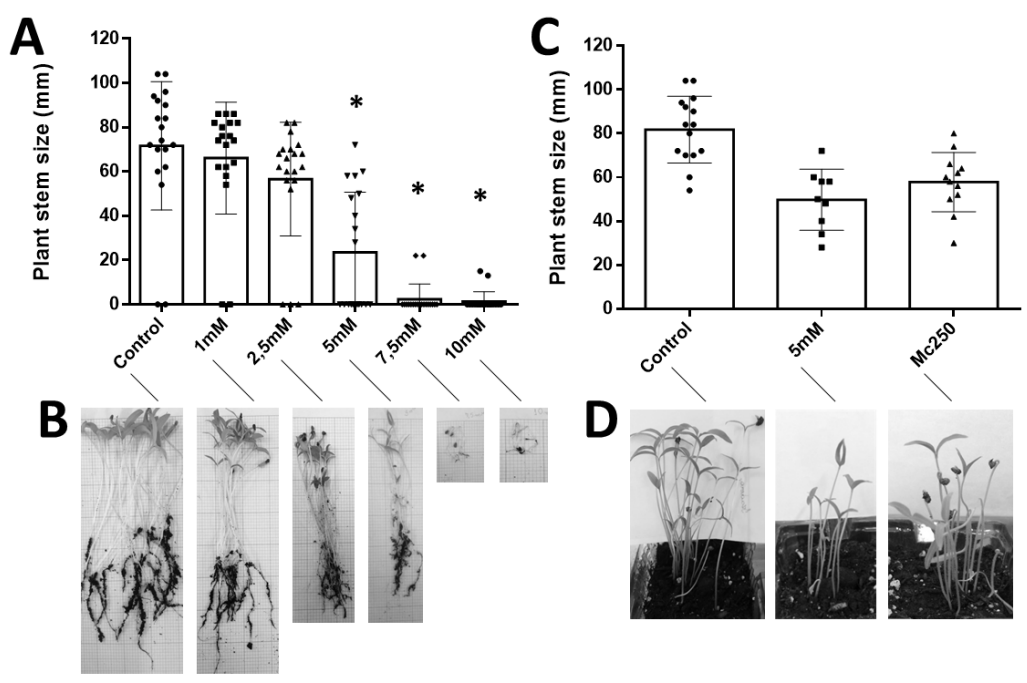

Figure $5 \mathrm{~A}$ ) Growth curve of tomato plants treated with $1 \mathrm{mM}, 2.5 \mathrm{mM}, 5 \mathrm{mM}, 7.5 \mathrm{mM}$, and $10 \mathrm{mM}$ of As (III) and untreated control. B) Tomato plants treated with As on each respective concentration. C) Growth curve of tomato plants in As-contaminated soil with $5 \mathrm{mM}$ of As (III) without the isolate, in the presence of A. faecalis strain Mc250, and untreated control. D) Tomato plants in the respective conditions of "C". The asterisk above bars indicate statistically significant difference among the groups compared to the control $(p<0.05)$. 


\section{Discussion}

\subsection{Bacteria as metal bioremediator agents and plant supporters}

High levels of trace elements are toxic for any organism due to blockage of biological functions or modification of essential protein structures (Tak et al., 2013). On the other hand, in small amounts, some heavy metals are essential for plant development and the absence of them induce the reduction of the growth rate (Tak et al., 2013).

Arsenic is a heavy metal extremely toxic to living organisms and its mechanisms of toxicity in plants is well known. Both the inorganic arsenic species (i.e. III and V) operate differently when absorbed by plants; however, they affect directly the growth of aerial parts, roots, and fruit production (Garg and Singla, 2011). As (V) competes with inorganic phosphate $(\mathrm{Pi})$ by binding its transport system (Pst) present in cellular membranes and interferes irreversibly in plant metabolism by acting directly on reactions that involve $\mathrm{Pi}$, such as cellular metabolism, DNA metabolism, and cell signaling (Finnegan and Chen, 2012). As (III) penetrates plant tissues by aquaporins, and once in contact with plant tissues it interferes in protein folding due to its ability to bind to sulfhydryl groups (Dixit et al., 2015). In both cases, the higher the heavy metals concentration, the higher the production of reactive species.

Plants have developed a sophisticated repertoire of molecular mechanisms to reduce damages caused by these metals. Some species are able to accumulate (hyperaccumulators), degrade, eliminate, translocate metals into their biomass, create a region surrounding the roots where the metal is precipitated and stabilized, or even convert metals into volatile compounds or less toxic forms (Mirza et al., 2014). In contrast, the survival of non-phytoaccumulator plants in metal-rich environ- ments is improved by the presence of a specialized microbial community (Seth et al., 2007). In addition to protect plants from toxic effects, these communities often facilitate nutritional uptake by enhancing plant growth (Tak et al., 2013). It has been demonstrated that As-resistant bacteria associated with Pteris vittata, a hyperaccumulator plant occurring on IQ that improve plant growth and help in metal removal (Han et al., 2016).

This study described for the first time the presence of Asresistant bacteria associated with roots and rhizosphere of Mimosa calodendron, an endemic and crucial species to positive interactions on FRG (Figure 1). One of the bacteria identified, belonging to the genus Alcaligenes, was analyzed for its potential in arsenic removal from As-contaminated environments as this isolate presented resistance to high As concentrations when compared to those already described in the literature (Kruger et al., 2013). Besides the resistance to such high concentrations, A. faecalis strain Mc250 has the in vitro capacity to remove respectively $55 \%$ and $72 \%$ of As (III) and As (V) in solution (Table 1). It is noteworthy that these assays were performed with much higher As concentrations than those found in natural environment (Vicq et al., 2015). Thus, its bioremediation potential might present better efficiency in natural conditions.

A morphological study through scanning electron microscopy (SEM) of A. faecalis strain Mc250 revealed that when treated with As (III) and As (V) they modified from rod-shaped to rounded shape (Figure 4). This morphology modification indicates metal accumulation and results from changes in the osmotic potential and cell turgor (Pandey and Bhatt, 2015). EDS analysis of $A$. faecalis strain Mc250 revealed that As was also adsorbed to the membrane (Figure 4). Similar data has been described by (Pandey and Bhatt, 2015) who showed increase in the area of one isolate as a positive response to As (V)-contaminated environment. The bioaccumulation of the isolated 
was confirmed by transmission electron microscopy (TEM) and EDX.

According to the hypothesis that this isolate could aid in plant growth in As-contaminated soil, tomato plants were used as a model since its growth rate is higher than FRG native plants. Tomato growth curve for different concentrations of As (III) was established (Figure 5A) in order to determine in which concentrations these assays would be performed. The results demonstrated that in $5 \mathrm{mM}$ not only the seeds germination was broken off, but there were also significant reduction in plant growth. In addition, while only 9 out of 20 seeds
(45\%) germinated in As-contaminated soil and in the absence of $A$. faecalis strain Mc250, 12 out of 20 seeds $(60 \%)$ germinated in soil contaminated in the presence of this isolate. Moreover, the growth rate of tomato plants in the presence of $A$. faecalis strain Mc250 was higher than in the absence of this isolate. In fact, heavy metals resistant bacteria can minimize toxicity by acting as plant growth promoters (Mallick et al., 2015). Therefore, the results presented in this study demonstrate for the first time the potential of bacteria associated with roots and rhizosphere of endemic plants from FRG as soil bioremediator agents (Figure 6).

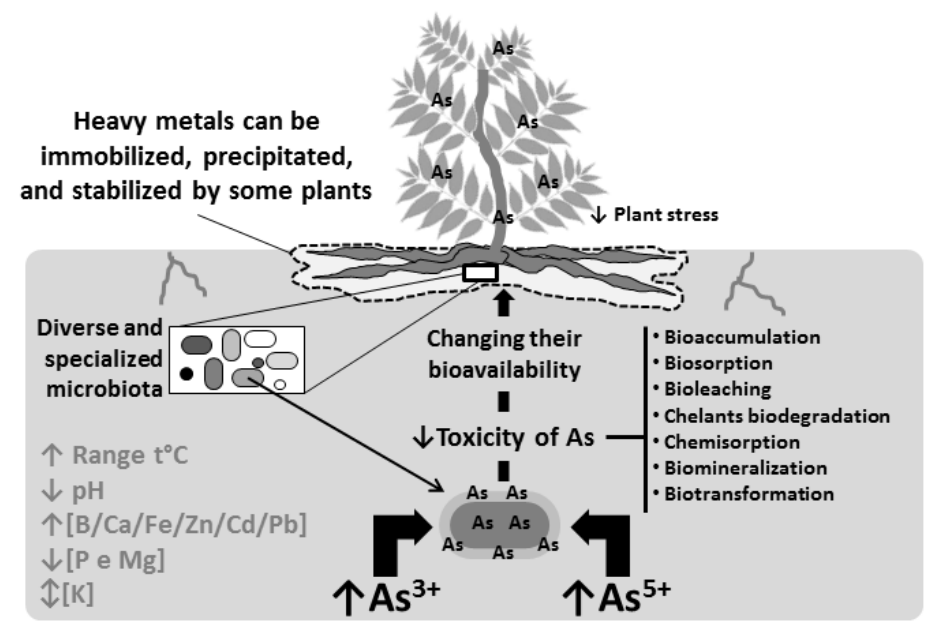

Figure 6. FRG are very restrictive to establishment of species due to great temperature variation, low $\mathrm{pH}$, soils with reduced availability of water and nutrients, low concentrations of phosphorous and magnesium, but high levels of metals such as iron and manganese, and anomalous concentrations of many different trace elements such as $\mathrm{Zn}, \mathrm{Pb}, \mathrm{Ni}, \mathrm{Cr}$, and $\mathrm{As}$. In order to reduce damage caused by these metals, some plants have developed molecular mechanisms to deal with such conditions. They can accumulate (hyperaccumulators), degrade, eliminate, translocate metals into their biomass, create a region surrounding the roots where the metal is precipitated and stabilized, or even convert metals into volatile compounds or less toxic forms. Furthermore, a specialized microbial community could modify metal bioavailability assisting hyperaccumulator and non-phytoaccumulator plants through different processes such as bioaccumulation, biosorption, bioleaching, chelants biodegradation, chemisorption, biomineralization, and biotransformation. These bacteria associated with endemic plants from FRG-IQ may benefit adaptive process facilitating the maintenance of this species in extreme environments. Thereby, to protect plants from toxic effects, these communities often facilitate nutritional uptake by enhancing plant growth. 


\section{2. $P G P R$ and plant maintenance in FRG: perspectives}

Environments with high metal concentration in soils as occur in FRG are very restrictive to the establishment of species (Jacobi et al., 2007) in view of the fact that it establishes a selective pressure which influences plant communities (Shure et al., 2007). According to Silveira et al. (2016), and following the guidelines established by Hopper, FRG presents the five characteristics necessary to be considered an Old ClimatellyBuffered Infertile Landscapes (OCBILs). According to the authors, the characteristics 4 and 5, which correspond respectively to nutritional and other biological specializations for resource acquisition and high vulnerability to soil removal, may also be justified by the presence of a specific and specialized microbiota. It is known that PGPR as well as other microorganisms associated with plants such as mycorrhizae play a key role in the adaptation of plants to these environments (Carvalho et al., 2012). Since the ecological diversity of a community can be determined by ecological and evolutionary processes (Heijden et al., 2008), plantbacteria interaction may be assumed as a mutualistic association originated from these processes that have occurred over generations and allowed colonization of metal-contaminated environments by plants. The results obtained in this study suggest that habitats colonized by plants in FRG soils is attributed not only to morphological adaptations of species (Alves and Kolbek, 1994), but also to molecular adaptations generated from interactions with bacteria.

Considering that iron-rich environments are usually habitat to rare flora characterized by high percentages of species with restricted geographical distribution (Silveira et al., 2016), it is possible that they are deeply associated with complex and restrictive coevolutionary processes (Grime, 1977). In this context, plants provide organic molecules originated from its metabolism for bacteria and other microorganisms, which in turn minimizes the potential damage that could be induced by metal and other soil components (or their deficiency, as in the case of P) to plant tissues. This is a possible explanation for the extreme plant vulnerability due to soil removal and consequently elimination of specialized microbiota associated with it.

Some authors describe the restoration of degraded areas in rupestrian grassland as a challenging process (Lambers et al., 2010). This is reiterated by some promising empirical attempts that, notwithstanding, still have low success (Stradic et al., 2015). According to the importance of microorganisms in the association between soil and plants, it is possible that this low success results from changes in the composition of the soil microbiota or its association with plant roots, which reduce the adaptive potential. Thus, the restoration studies should be complemented by studies of soil microbial ecology maintenance.

Silveira et al. (2016) recently reported that despite the increase in the last two decades in the number of indexed scientific articles on FRG and related topics, they are still incipient and polarized in some areas of scientific knowledge, which explain the neglected study of one of the most biologically diverse and endangered ecosystems of the word. This is even more noticeable in studies related to microorganisms associated with this environment. This study, therefore, provides a wide range of opportunities to understand the real role of microorganisms associated with soil and plants of FRG, allowing the discovery of new microorganisms (due to the high number of endemic plants in this region and its geological and evolutionary origin), as well as metabolic pathways, genes, and metabolites with wide ecological and biotechnological interest. In this case, products and processes that could be conjectured as ecosystem services, also neglected, could be used as scientifically-based conservation strategies to support proposals for the conservation of ferruginous fields. 


\section{Conclusions}

The results presented in this study, provides not only a great opportunity for new investigations that may assist in understanding the adaptation of metallophyte plants, but also signals the biotechnological potential of microorganisms in a neglected environment in systematics and in-depth scientific studies. Taking other models of plant-bacteria interaction in hostile environments as reference, it is possible to infer that the PGPR in rupestrian grassland also develop a key role in the system ecology allowing survival and maintenance of plant species from this environment. Thus, the acquisition of more isolates from a larger number of plants in this region is required for complementary scientific contributions about the microbiota from FRG.

\section{Acknowledgements}

The authors express their gratitude to the staff of the Laboratory of Biochemistry and Molecular Biology (LBBM, Federal University of Ouro Preto, UFOP) for their support. Ney Sampaio and NanoLab of Centro Minero-Metalúrgico da Rede Temática em Engenharia de Materiais (CMM-REDEMAT) are thanked for spectroscopy and microscopy analyses, respectively. Funding for this work was provided by the following agencies: Conselho Nacional de Desenvolvimento Científico e Tecnológico (CNPq) and Coordenação de Aperfeiçoamento de Pessoal de Nivel Superior (CAPES). Thanks to Prof. João Carlos Setubal (IQ-USP) for the help with assembly and identification of the sequence deposited at Genbank.

\section{References}

Alves, R.J.V., Kolbek, J. 1994. Plant species endemism in savanna vegetation on table mountains (Campo Rupestre) in Brazil. Vegetatio. 113, 125-139.

Banerjee, A., Bareh, D.A., Joshi, S.R. 2017. Native microorganisms as potent bioinoculants for plant growth promotion in shifting agriculture (Jhum) systems. Journal of Soil Science and Plant Nutrition. $17,127-140$.

Carmo, F.F., Jacobi, C.M. 2012. Vascular plants on cangas," in Floristic Diversity of the Quadrilátero Ferrífero Cangas, eds. C.M. Jacobi \& F.F. Carmo. (Belo Horizonte: IDM Ltda), 43-50.

Carmo, F.F., Jacobi, C.M. 2016. Diversity and plant trait-soil relationships among rock outcrops in the Brazilian Atlantic rainforest. Plant and Soil. 403, 7-20.

Carvalho, F., Souza, F.A., Carrenho, R., Moreira, F.M.d.S., Jesus, E.d.C., Fernandes, G.W. 2012. The mosaic of habitats in the high-altitude Brazilian rupestrian fields is a hotspot for arbuscular mycorrhizal fungi. Applied Soil Ecology. 52, 9-19.

Dixit, G., Singh, A.P., Kumar, A., Dwivedi, S., Deeba, F., Kumar, S., et al. 2015. Sulfur alleviates arsenic toxicity by reducing its accumulation and modulating proteome, amino acids and thiol metabolism in rice leaves. Sci. Rep. 5, 16205.

Finnegan, P.M., Chen, W. 2012. Arsenic toxicity: the effects on plant metabolism. Frontiers in Physiology. 3, 1-18.

Focardi, S., Pepi, M., Ruta, M., Marvasi, M., Bernardini, E., Gasperini, S., et al. 2010. Arsenic precipitation by an anaerobic arsenic-respiring bacterial strain isolated from the polluted sediments of Orbetello Lagoon, Italy. Letters in Applied Microbiology. 51, 578-585. 
Garg, N., Singla, P. 2011. Arsenic toxicity in crop plants: physiological effects and tolerance mechanisms. Environ. Chem. Lett. 9, 303-321.

Ginocchio, R., Baker, A.J.M. 2004. Metallophytes in Latin America: A remarkable biological and genetic resource scarcely known and studied in the region. Revista Chilena de Historia Natural. 77, 185-194.

Grime, J.P. 1977. Evidence for the Existence of Three Primary Strategies in Plants and Its Relevance to Ecological and Evolutionary Theory. The American Naturalist. 111, 1169-1194.

Han, Y.H., Fu, J.W., Chen, Y., Rathinasabapathi, B., Ma, L.Q. 2016. Arsenic uptake, arsenite efflux and plant growth in hyperaccumulator Pteris vittata: Role of arsenic-resistant bacteria. Chemosphere. 144, 1937-1942.

Heijden, M.G.A., Bardgett, R.D., Straalen, N.M.v. 2008. The unseen majority: Soil microbes as drivers of plant diversity and productivity in terrestrial ecosystems. Ecology Letters. 11, 296-310.

Jacobi, C.M., Carmo, F.F., Vincent, R.C., Stehmann, J.R. 2007. Plant communities on ironstone outcrops: a diverse and endangered Brazilian ecosystem. Biodiversity and Conservation. 16, 21852200 .

Jimtha, J.C., Jishma, P., Arathy, G.B., Anisha, C., Radhakrishnan, E.K. 2016. Identification of plant growth promoting Rhizosphere Bacillus sp. WG4 antagonistic to Pythium myriotylum and its enhanced antifungal effect in association with Trichoderma. Journal of Soil Science and Plant Nutrition. 16, 578-590.

Kruger, M.C., Bertin, P.N., Heipieper, H.J., ArsènePloetze, F. 2013. Bacterial metabolism of environmental arsenic-mechanisms and biotechnological applications. Appl. Microbiol. Biotechnol. 97, 3827-3841.
Lambers, H., Brundrett, M.C., Raven, J.A., Hopper, S.D. 2010. Plant mineral nutrition in ancient landscapes: high plant species diversity on infertile soils is linked to functional diversity for nutritional strategies. Plant Soil. 334, 11-31.

Mallick, I., Islam, E., Mukherjee, S.K. 2015. Fundamentals and Application Potential of ArsenicResistant Bacteria for Bioremediation in Rhizosphere: A Review. Soil and Sediment Contamination: An International Journal. 24, 704-718.

Matias, S.R., Pagano, M.C., Muzzi, F.C., Oliveira, C.A., Carneiro, A.A., Horta, S.N., et al. 2009. Effect of rhizobia, mycorrhizal fungi and phosphate-solubilizing microorganisms in the rhizosphere of native plants used to recover an iron ore area in Brazil. European Journal of Soil Biology. 45, 259-266.

Mirza, N., Mahmood, Q., Maroof Shah, M., Pervez, A., Sultan, S. 2014. Plants as useful vectors to reduce environmental toxic arsenic content. The Scientific World Journal. ID 921581, 11 pages.

Pandey, N., Bhatt, R. 2015. Arsenic resistance and accumulation by two bacteria isolated from a natural arsenic contaminated site. Journal of Basic Microbiology. 55, 1275-1286.

Salgado, A.A.R., Carmo, F.F. 2015. Quadrilátero Ferríferò: A beautiful and neglected landscape between the gold and iron ore reservoirs. In: Vieira B., Salgado A., Santos L. (eds) Landscapes and Landforms of Brazil. World Geomorphological Landscapes. Springer, Dordrecht 319-330.

Seshadri, B., Bolan, N.S., Naidu, R. 2015. Rhizosphere-induced heavy metal(loid) transformation in relation to bioavailability and remediation. Journal of Soil Science and Plant Nutrition. 15, 524-548. 
Seth, C.S., Chaturvedi, P.K., Misra, V. 2007. Toxic effect of arsenate and cadmium alone and in combination on giant duckweed (Spirodela polyrrhiza L.) in response to its accumulation. Environmental toxicology. 22, 539-549.

Shure, D.J., Ragsdale, H.L. 2007. Patterns of primary succession on granite outcrop surfaces. Ecology. 58, 993-1006.

Silveira, F.A.O., Negreiros, D., Barbosa, N.P.U., Buisson, E., Carmo, F.F. 2016. Ecology and evolution of plant diversity in the endangered campo rupestre: a neglected conservation priority. Plant and Soil. 403, 129-152.

Stradic, S.L.E., Silveira, F.A.O., Buisson, E., Cazelles, K., Carvalho, V., Fernandes, G.W., et al. 2015. Diversity of germination strategies and seed dormancy in herbaceous species of campo rupestre grasslands. Austral Ecology. 40, 537-546.
Tak, H.I., Ahmad, F., Babalola, O.O. 2013. Advances in the Application of plant growth-promoting rhizobacteria in phytoremediation of heavy metals. Rev. Environ. Contam. Toxicol. 223, 33-52.

Versalovic, J., Koeuth, T., Lupski, J.R. 1991. Distribution of repetitive DNA sequences in eubacteria and application to fingerprinting of bacterial genomes. Nucleic Acids Res. 19, 6823-6831.

Vicq, R., Matschullat, J., Leite, M.G.P., Nalini, Jr.H.A., Mendonça, F.P.C. 2015. Iron Quadrangle stream sediments, Brazil: geochemical maps and reference values. Environ. Earth Sci. 74, 4407-4417.

Vincent, R.D.C., Meguro, M. 2008. Influence of soil properties on the abundance of plant species in ferruginous rocky soils vegetation, southeastern Brazil. Revista Brasileira de Botânica. 31, 377-388. 